\title{
RECONNAISSANCE GEOLOGICAL OBSERVATIONS ON PRECAMBRIAN AND PALAEOZOIC ROCKS OF THE NEW AND SALISBURY RIVERS, SOUTHERN TASMANIA
}

\author{
by Grant Dixon and Chris Sharples
}

(with five text-figures)

DIXON, G. and SHARPLES, C., 1986(12:ix): Reconnaissance geological observations on Precambrian and Palaeozoic rocks of the New and Salisbury Rivers, southern Tasmania. Pap. Proc. R. Soc. Tasm. 120: 87-94.

https://doi.org/10.26749/rstpp.120.87 ISSN 0080-4703. University of Tasmania, Hobart, Tasmania, Australia, 7000.

Phyllite and quartzite, probably Precambrian, trend meridionally and dip steeply in the New River Gorge above the junction with the Salisbury River in southern Tasmania. Further upstream an association of silty dolomite and conglomerate is less deformed and may be younger. Siliceous conglomerate boulders occur in the New River below the gorge. Late Ordovician carbonates of the Gordon Group are exposed in the New Rivervalley just above the junction with the Salisbury River and up the Salisbury to Vanishing Falls, above which a sheet of Jurassic dolerite seems to have been intruded along the unconformity between the Ordovician rocks and almost horizontal Late Palaeozoic sedimentary rocks of the Parmeener Supergroup.

Key words: Precambrian, Ordovician, Tasmania.

\section{INTRODUCTION}

The New and Salisbury Rivers drain a remote area of southern Tasmania. The New River flows southeast from Federation Peak, and passes through a gorge $8 \mathrm{~km}$ long before reaching a broad alluvial valley where it is joined by the Salisbury River and flows southwardsinto New River Lagoon on the south coast of Tasmania. The Salisbury River flows northwards from Precipitous Bluff and over Vanishing Falls before turning westward to flow into the New River (fig. 1). Due to the rugged topography, dense vegetation and absence of tracks, these areas have been rarely visited.

Few geological observations have been made on these rivers. Johnston ( 1888) reported "Silurian" limestones containing the coral Strombodes. An exact location was not given, but Johnston mapped limestone as occurring for about $10 \mathrm{~km}$ or so up New River north of the lagoon. Hall (1966) recorded geological observations on the downstream end of the New River gorge which broadly agree with the observations reported in this paper, but differ in some significant details. It is not clear whether the observations recorded in Hall (1966) were made on the ground or by aerial reconnaissance; if the latter was the case it would explain the discrepancies with the present work. A more recent helicopter reconnaissance (Burrett et al. 1981 and Burrett pers. comm.) recorded Gordon Group (Burrett $e t$ al. 1984) limestones on the Salisbury River and a possible outcrop of Denison Group (Burrett el al.
1984) conglomerates on the New River just upstream of its confluence with the Salisbury River (the present work suggests that the "outcrop" observed on the New River was actually an allochthonous boulder). Additionally, on the basis of observations and collections made by bushwalkers it has been known for a decade that limestones exist on the Salisbury River at and below Vanishing Falls (Burrett 1978, Farmer 1979).

A topographic depression (referred to here as the "New River Depression") just south of the New River gorge, led to the assumption that carbonate rocks exist in that area.

The present paper records observations made on two occasions. In January/February 1984, Grant Dixon led an Australia and New Zealand Scientific Exploration Society (ANZSES) party down the entire length of the Salisbury River, making the observations reported here; and in January 1985 both authors entered the New River at the upstream end of its gorge and made observations down to New River Lagoon.

All grid references in this paper refer to the Universal Grid Reference System on the Huon 1:100 000 topographic map sheet 8211 (Tasm. Lands Dept 1977). UTGD specimen numbers refer to specimens housed in the Geology Department collection, University of Tasmania. 


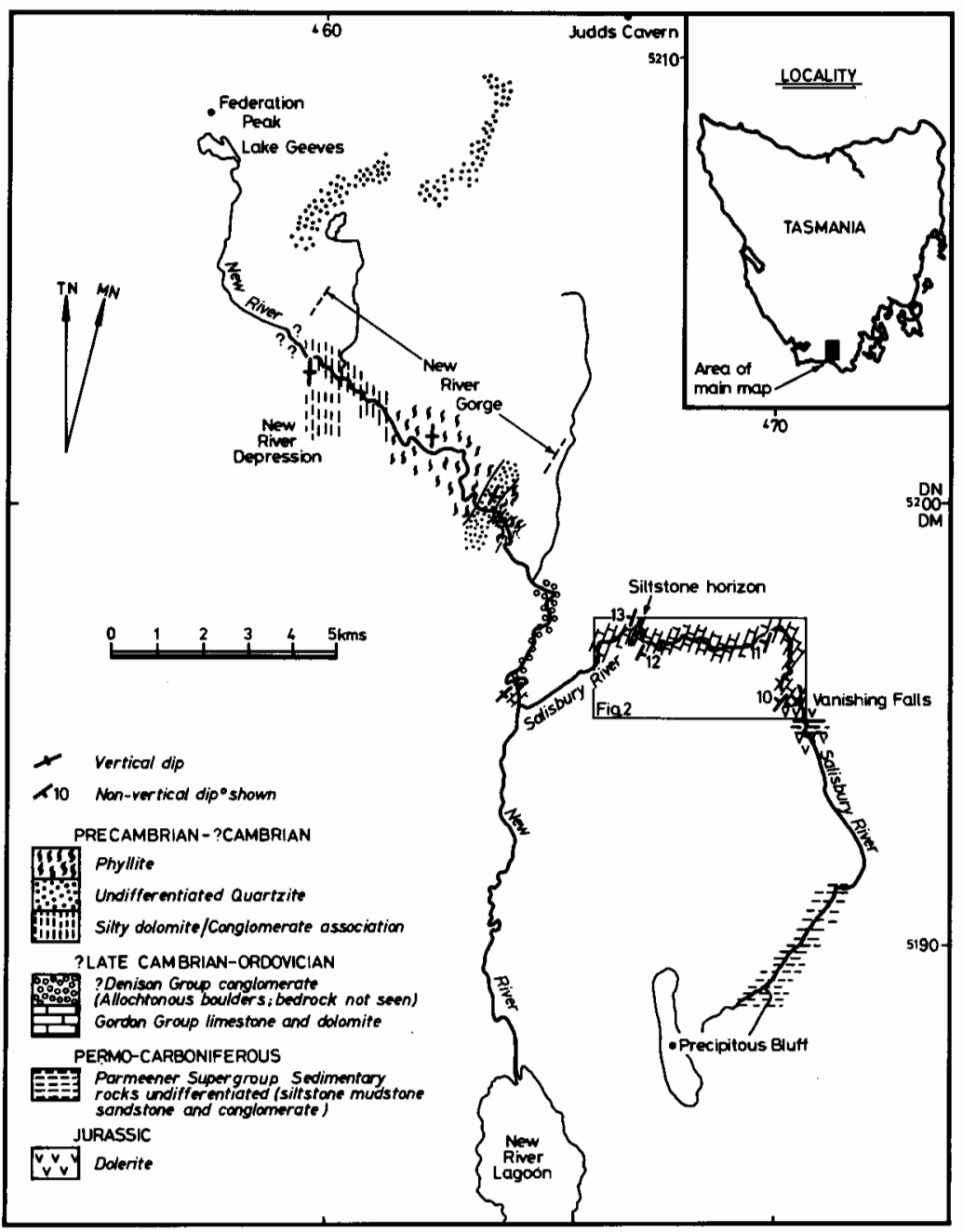

FIG.1 - Geological sketch map of the New and Salisbury Rivers, southern Tasmania, showing only

\section{STRATIGRAPHY \\ Presumed Precambrian to possible Cambrian}

The following three rock types and associations crop out in the New River gorge, and on the high ridge north of the gorge (although the units on the ridge do not necessarily correlate directly with the units in the gorge).

\section{Banded Grey Phyllite}

This unit outcrops in the New River gorge. The furthest upstream outcrop observed is at DN614020, and the furthest downstream outcrop the geological observations described in the accompanying paper.

is at DM640995. Two major quartzite horizons within the phyllite are described separately below. The phyllite is grey, greenish or rarely pinkish, with light and dark bands $10 \mathrm{~mm}$ or so thick throughout. Mica is abundant. At least two generations of complex small-scale folds are ubiquitous. Although major fold closures were not observed, major tilting has occurred along north-south trends. Dips a re very steep, varying from about $70^{\circ}$ towards the east (e.g. at DN614020) to vertical to about $70^{\circ}$ towards the west (e.g. at DN632007). Strikes are approximately meridional. Folded quart $z$ veins are common, and jointing of several trends occurs. 


\section{Quartzites}

At the eastern end of the high ridge north of the New River gorge, at approximately DN625070, white and pink quartzites occur, which are bedded on a scale of about $0.5 \mathrm{~m}$ and have cross-lamination structures. Conglomerate interbeds are present. At the western end of the aforementioned ridge, at approximately DN600067, white quartzites occur with complex small-scale folding.

Two quartzite bands occur close together within the phyllite at the downstream end of the New River gorge. Grey phyllite is observed in outcrop upstream, downstream and in between the two quartzite bands, but the contacts were not observed. The thickest quartzite band forms a high narrow ridge known as "Gibraltar", which the river cuts through at DM634998 to form a deep and dramatic chasm. The quartzite here is hard and white or purplish/red, with abundant white quartz veins. The quartzite dips vertically or very steeply towards the east, with an approximately northnortheast strike. The smaller quartzite band crops out in a short, narrow chasm at DM640996, a few hundred metres downstream from the main quartzite band, and is of similar appearance to the latter.

\section{Silty Dolomite/Conglomerate Association}

Interbedded silty dolomite and coarse conglomerate crop out in the upstream part of the New River gorge (fig. 1), from approximately DN596033 or further upstream, to a point upstream of DN614020. The contact with the phyllites which crop out at DN614020 was not observed, the last outcrop in a downstream direction being at DN612023.

The silty dolomite appears as a fine-grained, reddish-brown to dark yellowish-brown sedimentary rock, well-bedded with planar to slightly crinkled bedding planes 1 to $2 \mathrm{~mm}$ apart. Some outcrops show crinkled white stringers about $1 \mathrm{~mm}$ thick along bedding planes. Quartz veins up to 100 $\mathrm{mm}$ thick commonly cut across bedding.

A stained thin section was prepared of a dolomite sample collected at DN600030 (UTGD 68100 ). The specimen has a dolomite microspar matrix $(0.05 \mathrm{~mm}$ diameter anhedral grains $)$ containing well-rounded oval intraclasts, averaging 2.0 to $4.0 \mathrm{~mm}$ long and 0.5 to $2.0 \mathrm{~mm}$ wide, of dolomite and minor ferroan dolomite spar. A strong alignment of the intraclasts gives the rock a distinct planar fabric. Quartz grains of silt to fine sand size occur in both the matrix and the intraclasts, constituting up to 10 percent of the total sediment. Opaque to light brown material (bituminous?) occurs in some of the intraclasts, and as elongate blobs in the matrix.

The conglomerate has 0.1 to $0.3 \mathrm{~m}$ diameter clasts in a closed framework. The clasts are wellrounded and are of white and pink quartzite. Some conglomerates appear "stretched", having a distinct alignment of clasts parallel to bedding, and some of the quartzite clasts have tension cracks filled with quartz. The silty dolomite and conglomerate are often seen in outcrop to be conformably interbedded, with conglomerate beds up to $3 \mathrm{~m}$ thick occurring in the silty dolomite. The silty dolomite appears to be the predominating lithology. These rocks dip vertically or sometimes steeply towards the east, and strike north-south. No evidence of small-scale folding was seen.

This dolomite/conglomerate association was observed in the New River gorge immediately north of the New River depression, which was not visited but can be tentatively assumed to contain the same dolomitic rocks.

\section{Age Relationships}

The phyllite and quartzite units observed in the New River gorge and on the high ridge north of the gorge are presumed to be Precambrian on the basis of their similarity to Precambrian rocks elsewhere in Tasmania. The silty doiomite/conglomerate association shows less evidence of deformation, and may therefore be a younger unit than the phyllites and quartzites. By comparison with dolomitic sediments elsewhere in Tasmania, the dolomite/conglomerate association may be of Late Precambrian to Cambrian age. However, the absence of facings, fossils or other evidence makes it difficult to assess the age relationships of the units in the New River gorge.

\section{Age Unknown}

An outcrop of well-bedded rock occurs on the New River at DM640990, below the gorge. A cursory examination showed that it was clearly neither conglomerate nor limestone. It dips approximately $30^{\circ}$ towards the south or southeast.

No other definite bedrock outcrops were identified on the New River from this point downstream to just above the Salisbury River junction.

\section{?Late Cambrian to Ordovician}

\section{?Denison Group Conglomerates}

From approximately DM645983 downstream to the Salisbury River confluence, many large boulders of reddish conglomerate, similar in appearance to Denison Group conglomerates elsewhere in Tasmania, 


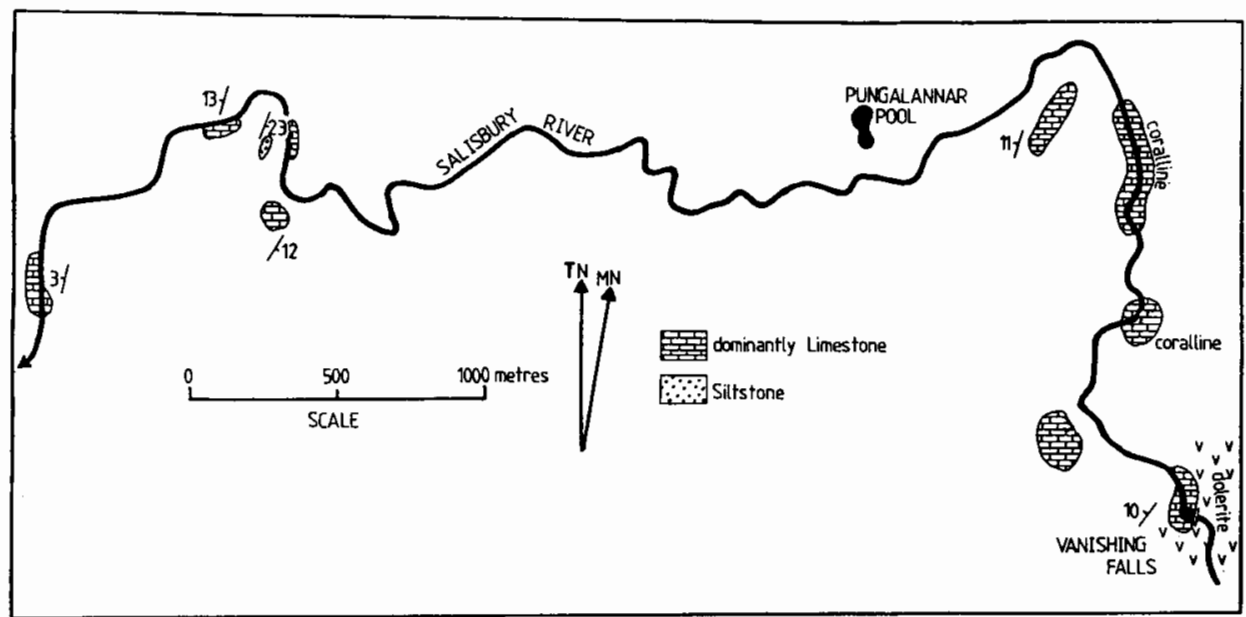

FIG.2 - Detail map showing Ordovician Gordon Group limestone outcrop localities, Salisbury River.

occur in the bed and banks of the New River. None of these boulders was obviously bed rock, and most were clearly allochthonous boulders. A supposed bedrock outcrop of this conglomerate recorded in Burrett et al. (1981) is possibly allochthonous, since a bedrock outcrop of dolomite occurs very close to the reported conglomerate "outcrop" location (see below). On topographic and structural (see Regional Structure) grounds it is likely that the conglomerate boulders are derived from a ridge immediately west of the section of river in which the boulders occur.

\section{Gordon Group Carbonates}

Carbonate rocks correlated with the Ordovician Gordon Group occur on both the New and Salisbury Rivers. New River: At DM643958, on the New River just upstream of the Salisbury River confluence, a block of dolomite $5 \mathrm{~m}$ long is probably an outcrop. It is exposed beneath river gravels in the west bank of the river. No macrofossils were seen, but the rock has a similar field appearance to Gordon Group limestones elsewhere in Tasmania, and Gordon Group limestones occur on the Salisbury River nearby.

The rock is medium grey, with slightly undulose bedding defined by light and dark bands 5 to $20 \mathrm{~mm}$ thick. The bedding is disrupted in places by small autobrecciation fractures along which the rock tends to break. The bedding is vertical or sub-vertical, striking $224^{\circ}$ True; facing is unknown.

Specimen UTGD 68101 is a uniform sparry dolomite (anhedral interlocking grains 0.1 to $0.2 \mathrm{~mm}$ in diameter) with no allochems or sedimentary structures apart from one slightly undulose $3 \mathrm{~mm}$ thick lamination of dolomicrite containing some spar and a few scattered quartz grains averaging $0.5 \mathrm{~mm}$ in diameter. Fine fractures, randomly oriented, occur throughout the specimen, and one fracture offsets the dolomicrite lamination. Dissolution of part of the sample failed to yield identifiable conodonts, although possible deformed conodonts are present (C. F. Burrett, pers. comm.) Salisbury River: Limestone of the Gordon Group crops out discontinuously in the Salisbury River valley downstream from Vanishing Falls to DM660965 (fig. 2). The top of the section is terminated by a dolerite sill at Vanishing Falls.

The total thickness of Gordon Group rocks is unknown due to lack of outcrop and apparent folding in the middle Salisbury valley. Time and weather considerations precluded any detailed observation of macrofossils and structures during this study. Nevertheless some generalisations can be made.

A stratigraphic section is illustrated in fig. 3 . The lowermost exposures consist of massively-bedded micrite, with calcareous mudstone beds occurring higher in the section. This is overlain by a 2 to $3 \mathrm{~m}$ thick, bedded siltstone unit, which is immediately overlain by interbedded dolomicrite and calcareous mudstone. A sample collected near here a decade ago contained a conodont fauna of middle-Late Ordovician age, as well as scolecodonts, chitinozoa and graptolite fragments (Burrett 1978 and pers. comm.).

A section of limestone, approximately $100 \mathrm{~m}$ thick, is exposed in the $2 \mathrm{~km}$ long gorge below Vanishing Falls. At DM700972 this consists of apparently unfossiliferous micrite. This is overlain by about $40 \mathrm{~m}$ of coralline limestone. This unit contains colonies 


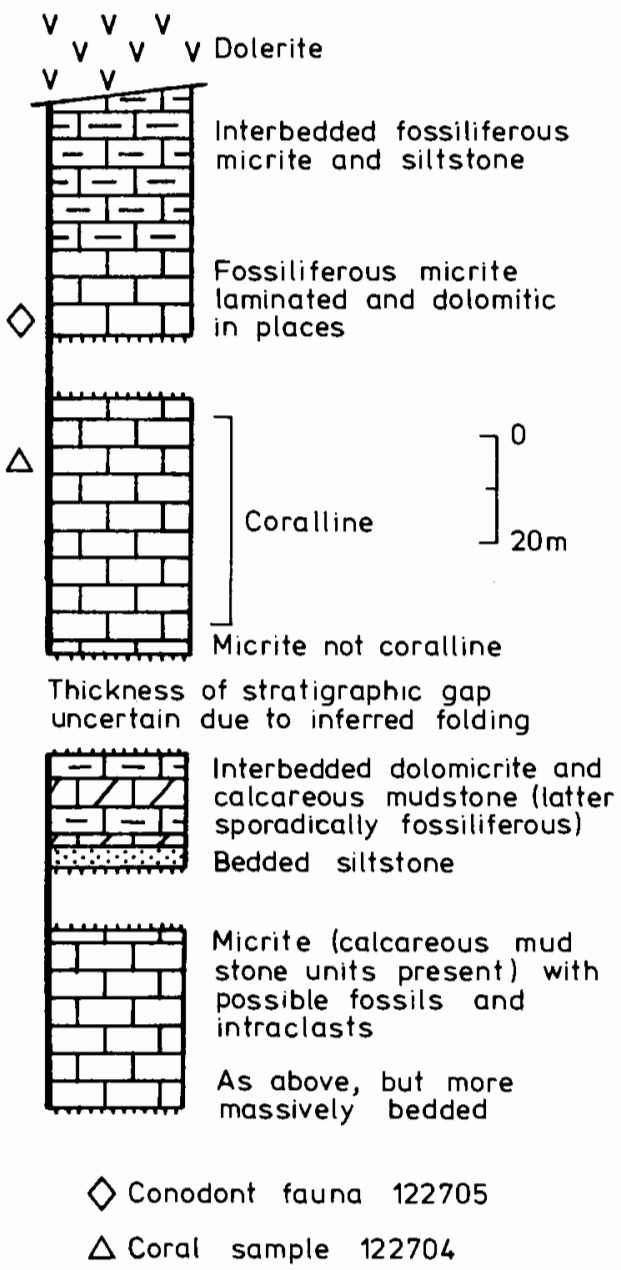

FIG.3-Geological column: Gordon Group, Salisbury River.

of Palaeofavosites sp. (sample UTGD 122704), similar to Kenna's (1978) species A, suggesting an age similar to that of the top of the Benjamin Limestone from the Florentine Valley (M.R. Banks, pers. comm.). The colonies are up to $0.7 \mathrm{~m}$ in diameter, in some cases no more than $1 \mathrm{~m}$ apart, and are often spectacularly exposed in water-polished riverbed outcrops. Small gastropods were observed between the colonies.

The coralline unit is overlain by a styolitic, silty, fossiliferous micrite. This probably represents greater detrital deposition post-dating the demise of the "reef". This unit (sample UTGD 122705, grid reference DM701958) contains stictoporid and trepostome bryozoa (including Rhombotrypa sp.), a few shelly fragments (including strophomenid brachiopods) and numerous echinoderm fragments. The matrix is relatively uncalcitic, consisting predominantly of quartz, sericite and shell fragments. A small tourmaline clast, an epidote (?) grain and rhombs of ferroan carbonate were noted. The sample shows little recrystallisation, and the echinoderm plates are some of the least altered of any Tasmanian Ordovician samples (M.R. Banks, pers. comm.).

A conodont fauna separated from sample UTGD 122705 contains Oulodus sp., suggesting an upper Middle to lower Upper Ordovician age, and also contains abundant probable conularid fragments. This fauna is similar to that occurring in coralline limestone in the Picton River, $20 \mathrm{~km}$ to the north (C.F. Burrett, pers. comm.).

The coralline unit appears to grade upward into interbedded fossiliferous micrite and siltstone occurring 

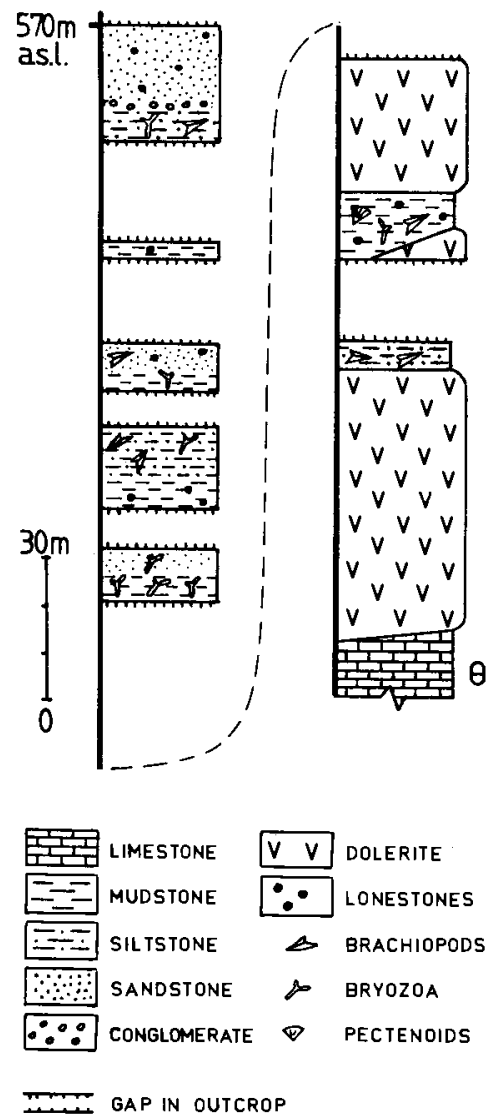

FIG.4 - Geological column: Parmeener Supergroup, Jurassic dolerite, upper Salisbury River.

at the base of Vanishing Falls. Here the limestone is virtually a calcsilicate hornfels for at least $5 \mathrm{~m}$ below the dolerite intrusion. A similar hornfels occurs adjacent to dolerite at Lake Sydney and has been interpreted as a correlate of the Eldon Group (Correy 1983). The more siliceous rocks at the base of Vanishing Falls may correlate with the base of the Eldon Group.

Burrett et al. (1984) suggest that deepening exhibited at Precipitous Bluff and the shallowing observed in the south coast carbonates happened isochronously in about Kirkfieldian time and indicate a substantial decrease in the depositional slope over a wide area of southern Tasmania. The New River Beds (Burrett et al. 1981) contain corals of sufficient abundance that the designation "reef" may be appropriate (Burrett et al. 1984). Similar "reefal" limestone near Vanishing Falls is significantly younger. It is likely that a landward migration (i.e. constant depth) of the reef during the transition of the Tasmanian platform from a rimmed shelf to a ramp (Burrett et al. 1984) occurred. The occurrence of still younger coralline limestone in the Picton River $20 \mathrm{~km}$ further north (Burrett 1978 and pers. comm.) may be significant in this regard.

\section{Late Palaeozoic}

Flat-lying sedimentary rocks of the Parmeener Supergroup (Banks 1973) crop out in the Salisbury River from DM715914 to DM692886 (fig. 1). In this area the river flows for up to several hundred metres over bedding planes, before descending in small cascades to further such planes. A stratigraphic section is illustrated in fig. 4. In general, the upper part of the section is less fossiliferous than the lower part.

In the vicinity of DM706950 outcrops of fossiliferous siltstone and mudstone are intruded by dolerite. The sedimentary rocks contain brachiopods, bryozoans (mostly fenestellids) and pectenoids, and are wellbedded. The fossil abundance varies significantly from bed to bed. The mudstone contains sparse quartzite lonestones up to $40 \mathrm{~mm}$ in diameter.

Upstream from DM715914 to DM701893 the Parmeener Supergroup consists of layers of richly-fossiliferous siltstone and poorly fossiliferous, usually dark mudstone. A low species diversity was noted (mainly Fenestella and strophomenid brachiopods). Rounded quartzite and quartz schist lonestones up to $50 \mathrm{~mm}$ in dia meter are common in the mudstone and the less fossiliferous siltstone.

At DM693887 well-bedded, grey, fenestellid siltstone is overlain by a "graded" conglomerate bed $1 \mathrm{~m}$ thick. In addition to Fenestella, the siltstone contains a few small brachiopods and, rarely, gastropods $20 \mathrm{~mm}$ in whorl diameter. The conglomerate is polymodal, with clasts of quartzite, quartz schist and conglomerate up to $150 \mathrm{~mm}$ in diameter. Overlying the conglomerate irregular thick beds of sandstone with quartzite and quartz schist lonestones, usually subangular and up to 150 $\mathrm{mm}$ in diameter, crop out for about $200 \mathrm{~m}$.

\section{Jurassic}

At Vanishing Falls (grid reference DM705955) the river plunges $70 \mathrm{~m}$ over a sill-like dolerite intrusion of presumed Jurassic age. The dolerite intrusion separates the Gord on Group limestones below from the Parmeener Supergroup rocks above. The latter are intruded again by dolerite upstream of the Falls (see fig. 4).

The dolerite crops out as an escarpment at Vanishing Falls, and discontinuously as riverbed outcrops for some $2 \mathrm{~km}$ upstream. Just north of Vanishing 


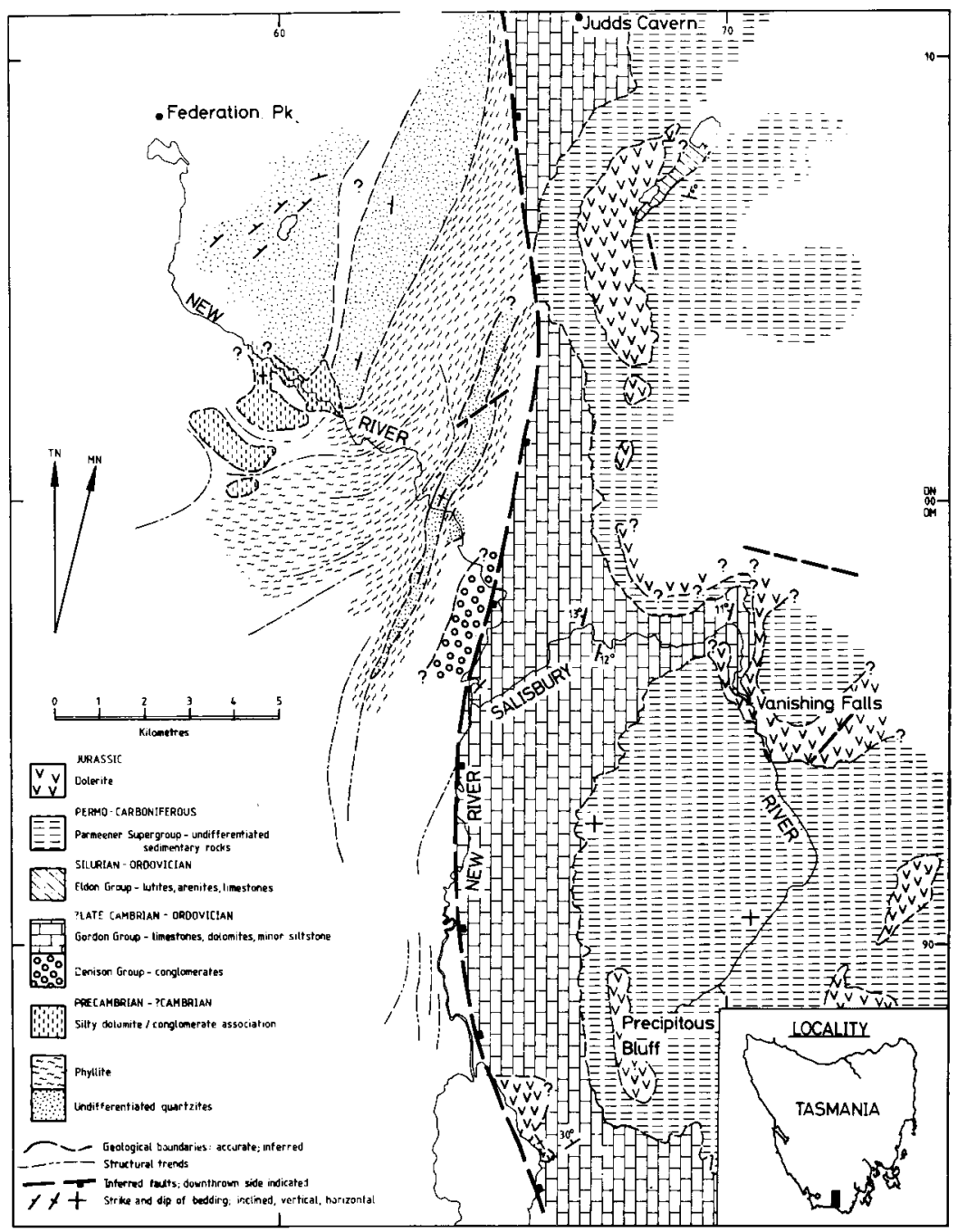

FIG.5 - Interpretive geological map of the New and Salisbury Rivers area, compiled from information in this paper, airphoto interpretation, Burrett et al.(1981) and Correy (1983).

Falls, the base of the dolerite sill appears to transgress to higher topographic levels on the west side of the Salisbury River.

\section{Quaternary}

No outcrop was observed in the New River bed below the Salisbury River junction. The river cuts through alluvium deposits containing predominantly dolerite cobbles and boulders. A few boulders of grey matrix-supported mixtite (Late Palaeozoic tillite?) were noted within $1 \mathrm{~km}$ or so below the Salisbury River junction.

\section{REGIONAL STRUCTURE}

Using airphoto interpretation in conjunction with ground information it is possible to construct a map of the regional structure (fig. 5). The most outstanding structural feature of the area is the approximately linear geological boundary marked by the lower-middle New River and the southern watershed of the Cracroft River. On the west side of this boundary Precambrian rocks occur at the same topographic levels as the Palaeozoic and Jurassic rocks on the eastern side. Whereas this could result from the Palaeozoic rocks lapping 
onto a Precambrian basement high, it has been suggested (Corbett 1970 and Burrett et al. 1981, p.98) that the geological boundary is the site of a major transcurrent fault. Burrett et al. (1981) suggest that vertically-dipping limestone at New River Lagoon and a shear zone at Point Cecil (south coast) support the existence of such a major fault (Berry \& Harley 1983, Bischoff 1983). In addition, the vertical dip, possible deformed conodonts and intense fracturing evident in the dolomite near the confluence of the New and Salisbury Rivers support major fault movement.

Whilst transcurrent movement along the postulated fault has not been proved and the amount of hoizontal shift is unknown, vertical movement would need to be of the order of hund reds of metres to account for the juxtaposition of Precambrian and Palaeozoic rocks. The probable existence of Denison Group bedrock west of the New River, above adjacent Gordon Group limestone, can be accounted for by the postulated fault. Based on airphoto interpretation and ground observations, the Precambrian quartzite and phyllite in the New River gorge area strike generally north-northeast, swinging westward southwest of the gorge. The relationship between the dolomite/ conglomerate association and the unit of quartzite and phyllite is unclear, and is probably structurally complicated.

The unconformity between the Ordovician limestone and Parmeener Supergroup rocks seems relatively horizontal between Judds Cavern and Precipitous Bluff, occurring at approximately 400 $m$ ASL over most of that distance, although a higher occurrence of Eldon Group rocks at Lake Sydney (Correy 1983) and an apparent lack of Ordovician limestone in the uppermiddle Farmhouse Creek area indicates variations in the unconformity surface east of Mt Bobs.

Precipitous Bluff, Mt Bobs, Bobs Knobs, Mt Bisdee and other mountains east of the New River appear to be erosional remnants of a single dolerite sill. The dolerite at Vanishing Falls crops out at a lower stratigraphic level, and observational and airphoto evidence suggest that the dolerite transgresses upwards from the Vanishing Falls area to join the upper dolerite sill at the southern end of Bobs Knobs.

\section{ACKNOWLEDGEMENTS}

We thank C.F. Burrett and M.R. Banks for useful discussions, criticisms and fossil identifications, C. Calver for useful discussions and criti- cisms, and the Australian and New Zealand Scientific Exploration Society (ANZSES) for making the Salisbury River trip possible.

\section{REFERENCES}

BANKS, M.R., 1973:General geology. In BANKS, M.R. (ed.) THE LAKE COUNTRY OF TASMANIA. Royal Society of Tasmania, Hobart: 25-34.

BERRY, R.F. \& HARLEY, S., 1983: Pre-Devonian stratigraphy and structure of the Prion Beach-Rocky Boat Inlet-Osmiridium Beach coastal section, Southern Tasmania. Pap. Proc. R. Soc. Tasm. 117: 59-75.

BISCHOFF, K., 1983: THE GEOLOG Y OF THE ROCKY $B O A T I N L E T-S U R P R I S E B A Y A R E A$. Unpubl. Hons. thesis, Univ. of Tasm.

BURRETT, C.F., 1978: MIDDLE-UPPER ORDOVICIAN CONODONTS AND STRATIGRAPHY OF THE GORDON LIMESTONE SUBGROUP, TASMANIA. Unpubl. Ph.D. thesis, Univ. of Tasm.

BURRETT, C.F., LAURIE, J. \& STAIT, B., 1981:Gordon Sub-group (Ordovician) carbonates at Precipitous Bluff and Point Cecil, southern Tasmania, Australia. Pap. Proc. R. Soc. Tasm. 115: 93-99.

BURRETT, C.F., STAIT, B., SHARPLES, C. \& LAURIE, J., 1984:Middle-Upper Ordovician shallow platform to deep basin transect, southern Tasmania, Australia. In BRUTON, D.L. (Ed.), ASPECTS OF THE ORDOVICIAN SYSTEM. Palaeontological Contribs. Univ. of Oslo, No. 295, Universitetsforlaget: 149-157.

CORBETT, K.D., 1970: SEDIMENTOLOGY OF AN UPPER CAMBRIAN FLYSCH SEQUENCE (DENISON GROUP) ON THE DENISON RANGE, TASMANIA. Unpubl. Ph.D. thesis, Univ. of Tasm.

CORREY, J.J., 1983: THE GEOLOGY OF THE ROCKS OF THE GORDON AND ELDON GROUP CORRELATESANDTHEPARMEENERSUPERGROUPIN THE MT BOBS-THE BOOMERANG AREA, SOUTHEASTERN TASMANIA. Unpubl. Hons, thesis, Univ. of Tasm.

FARMER, N., 1979:Geological atlas 1:250000 series. Sheet SK-55/8. Hobart. Explan. Rept Dept Mines Tasm.

HALL, W.D.M., 1966:Interim geological report on the southwest portion of exploration licence 13/65, southwest Tasmania. Unpubl. rept, Broken Hill Prop. Co. Ltd, June 1966.

JOHNSTON, R.M., I888: SYSTEMATIC ACCOUNTOF THE GEOLOG Y OF TASMANIA. Government Printer, Hobart, Tasmania.

KENNA, K., 1978: TABULATE AND HELIOLITID CORALS OF THE DEN CORALLINE MEMBER AT MOLE CREEK AND THE FIELD WEST CORALLINE SEQUENCES AT WESTFIELD. Unpubl. Hons. thesis, Univ. of Tasm.

(accepted Aug. 30, 1985) 